\title{
DETERMINANTS OF COMPLIANCE WITH PERSONAL TAX OBLIGATION: DO TAX AMNESTY PLAY?
}

\author{
Resshe Serlly Gita ${ }^{1}$, Amir Hidayatulloh ${ }^{2}$ \\ ${ }^{12}$ Universitas Ahmad Dahlan, Indonesia \\ ressheserllygita@gmail.com \\ amir.hidayatulloh@act.uad.ac.id
}

\begin{tabular}{|c|c|}
\hline INFO ARTIKEL & ABSTRACK \\
\hline $\begin{array}{l}\text { Histori Artikel: } \\
\text { Tgl. Masuk : } 08 \text { Juli } 2019 \\
\text { Tgl. Diterima : } 28 \text { September } 2019 \\
\text { Tersedia Online : 30 September } 2019 \\
\text { Keywords: } \\
\text { Taxpayer Compliance, Tax } \\
\text { Service, Tax Amnesty, Tax } \\
\text { Knowledge, Tax Saction }\end{array}$ & $\begin{array}{l}\text { This study aims to analyse the effect of tax services, tax } \\
\text { amnesty, taxation knowledge, and tax sactions on taxpayer } \\
\text { compliance. The population in the study is an individual } \\
\text { taxpayer in the city of Yogyakarta. The sample in the study } \\
\text { was an individual taxpayer in the city of Yogyakarta, and } \\
\text { took part in the tax amnesty program. The sampling } \\
\text { technique in this study used the convenience sampling } \\
\text { method. Responden in the study amounted } 60 \\
\text { respondents. The data anlysis technique in this study used } \\
\text { multiple linear regression analysis. This study obtained } \\
\text { result that taxpayer compliance in influenced by tax } \\
\text { services and tax amnesty programs. However, taxation } \\
\text { knowledge and tax saction does not affect taxpayer } \\
\text { compliance. The cause of taxation knowledge does not } \\
\text { affest taxpayer compliance, perhaps the understanding of } \\
\text { taxpayers regarding the procedures for payment and } \\
\text { reporting is still minimal. Meanwhile, the reason for lack of } \\
\text { support fot tax sanction on taxpayer compliance, perhaps } \\
\text { because taxpayers consider that saction given when } \\
\text { taxpayer violate laws are still mild. Therefore, these two } \\
\text { reasons are factors that encourage taxpayers to behave } \\
\text { disobediently. }\end{array}$ \\
\hline
\end{tabular}

\section{PENDAHULUAN}

Pajak adalah sumber negara terbesar, serta sumber pembiayaan yang penting bagi negara. Hal ini dapat kita lihat dari postur Anggaran Penerimaan dan Belanja Negara (APBN) tahun 2018 sebesar Rp1.618,1 triliun yang berasal dari sektor pajak. Pada tahun 2018, penerimaan pajak mengalami peningkatan sebesar 10 persen dibandingkan dengan tahun 2017. Penerimaan pajak pada tahun 2017 sebesar Rp1.472,7 triliun (www.kemenkeu.go.id, 2018)

Menurut (Tiraada, 2013), penerimaan dan pendapatan Negara akan meningkat seiring dengan meningkatnya kepatuhan masyarakat untuk memenuhi kewajiban perpajakannya. Hal ini berarti bahwa ketika semua wajib pajak memiliki kepatuhan dalam membayar pajak, maka pembangunan akan berjalan dengan lancar, serta target penerimaan dari sektor pajak dapat tercapai. Kepatuhan wajib pajak dapat ditingkatkan dengan peningkatkan kualitas pelayanan fiskus. Pelayanan fiskus yang baik akan memberikan kenyamanan bagi wajib pajak. Pelayanan fiskus meliputi keramahtamahan petugas, dan kemudahaan sistem informasi perpajakan.

Optimalisasi penerimaan negara dari sektor pajak dapat dilakukan melalui dua cara yaitu intensifikasi dan ekstensifikasi perpajakan. Upaya intensifikasi dapat dilakukan dengan menambah jumlah wajib pajak, sedangkan upaya ekstensifikasi yaitu dengan 
memperluas objek pajak. Salah satu kebijakan yang dapat dipertimbangkan dalam rangka meningkatkan subjek pajak dan objek pajak adalah tax amnesty (pengampunan pajak). Program tax amnesty bukan hal baru dalam dunia perpajakan. Tax amnesty pernah dilakukan di Argetina, Thailand, Indonesia, Korea Selatan, Fiji, Pakistan (Finansial.bisnis.com, 2018).

Program tax amnesty sangat
membantu
memperbaiki perekonomian, pembangunan, mengurangi pengangguran, mengurangi kemiskinan serta memperbaiki ketimpangan sosial. Namun, kebijakan tax amnesty harus diikuti dengan repatriasi sebagian atau keseluruhan aset orang Indonesia yang tersimpan diluar negeri. Sehingga, ketika kebijakan tax amnesty dan repatriasi berjalan seiringan, maka kebijakan tersebut dapat membantu pemerintah dalam menstabilitaskan ekonomi makro (Rezy, 2016).

Menurut (Ghoni, 2014), salah satu faktor yang memengaruhi kepatuhan wajib pajak adalah pengetahuan perpajakan. Pengetahuan perpajakan memiliki peran penting untuk menumbuhkan kepatuhan wajib pajak. Sehingga, ketika wajib pajak memiliki pengetahuan perpajakan yang mencukupi, maka wajib pajak tersebut dengan mudah melaksanakan kewajiban perpajakannya.

Faktor lain yang dapat memengaruhi kepatuhan wajib pajak adalah sanksi pajak (Irmawati \& Hidayatulloh, 2019); (Siamena \& Sabijono, Hariyanto Warongan, 2017); (Tiraada, 2013);(Muliasari \& Setiawan, 2011). Lebih lanjut, (Tiraada, 2013) menyatakan bahwa sanksi pajak adalah faktor yang memberikan pengaruh cukup besar terhadap kepatuhan wajib pajak.

Beberapa penelitian sudah meneliti mengenai pelayanan fiskus, tax amnesty, pengetahuan pajak, dan sanksi pajak terhadap kepatuhan wajib pajak. Akan tetapi, hasil penelitian terdahulu masih kontradiktif, antara lain, (Sari, 2017) yang menyatakan bahwa pelayanan fiskus tidak berpengaruh terhadap kepatuhan wajib pajak. Begitu juga dengan (Ragimun, 2015) yang menyatakan bahwa tax amnesty pernah dilakukan di Indonesia akan tetapi kurang efektif. Penyebab ketidak efektifan tersebut disebabkan ketidakjelasan tujuan dan aturan, serta tidak mendukungnya sarana dan prasarana.

Program tax amnesty di kota Yogyakarta mengalami peningkatan dalam sisi jumlah peserta. Sehingga, ketika dilihat dari sisi jumlah pesertanya, program tax amnesty di kota Yogyakarta direspon baik oleh masyarakat. Kementerian Keuangan mencatat ada peningkatan jumlah penerimaan pajak pada Januari 2018 dibandingkan dengan perioda yang sama, yakni bulan Januari pada tahun-tahun sebelumnya. Bahkan Sri Mulyani selaku Menteri Keuangan menyatakan bahwa penerimaan pajak Januari 2018 adalah penerimaan pajak tertinggi selama empat tahun terakhir (Mulyani, 2018).

Realisasi penerimaan pajak bulan Januari 2018 sebesar Rp78,94 triliun atau mengalami pertumbuhan 11,7 persen dari tahun ke tahun. Sri Mulyani selaku Menteri Keuangan menjelaskan bahwa jika tidak memperhitungkan penerimaan dari uang tebusan tax amnesty, maka pertumbuhan penerimaan pajak Januari 2018 mencapai 11,88 persen dibandingkan dengan Januari 2017 (Mulyani, 2018).

\section{KERANGKA TEORITIS DAN PENGEMBANGAN HIPOTESIS Pajak}

Pajak adalah kontribusi wajib kepada Negara yang pemungutannya didasarkan pada undang-undang, tanpa imbalan secara langsung, dan digunakan untuk kepentingan masyarakat (Undangundang Nomor 28, 2007).

Pajak memiliki dua fungsi yaitu fungsi anggaran dan fungsi pengatur. Pajak berfungsi sebagai anggaran karena pajak adalah salah satu sumber penerimaan Negara. Sedangkan, pajak berfungsi sebagai pengatur karena pajak mengatur kehidupan ekonomi maupun sosial (Mardiasmo, 2009).

\section{Pelayanan Fiskus}

Menurut (Jatmiko, 2006); (Arum, 2012), pelayanan merupakan cara 
membantu, mengurus, atau menyiapkan segala keperluan yang dibutuhkan seseorang. fiskus adalh petugas pajak. Sehingga, pelayanan fiskus adalah cara petugas pajak dalam membantu mengurus atau menyiapkan segala keperluan yang dibutuhkan wajib pajak.

Kualitas pelayanan fiskus sangat berpengaruh terhadap wajib pajak dalam membayar pajaknya. Oleh karena itu, fiskus dituntut untuk memberikan pelayanan yang ramah, adil, dan tegas setiap saat kepada wajib pajak serta dapat memupuk kesadaran masyarakat tentang tanggung jawab membayar pajak. Pemberian jasa oleh aparat pajak kepada wajib pajak besar manfaatnya sehingga dapat menimbulkan kesadaran wajib pajak dalam memenuhi kewajiban perpajakannya.

\section{Tax Amnesty}

tax amnesty adalah penghapusan pajak yang seharusnya terutang, tidak dikenai sanksi administrasi perpajakan dan sanksi pidana di bidang perpajakan dengan cara mengungkap harta serta membayar uang tebusan sebagaimana telah diatur dalam undang-undang (Undang-Undang Republik Indonesia Nomor 11, 2016).

Lebih lanjut (Undang-Undang Republik Indonesia Nomor 11, 2016), ada tiga tujuan tax amnesty. Tujuan tersebut meliputi (1) mempercepat pertumbuhan dan restrukturisasi ekonomi, (2) mendorong reformasi perpajakan menuju sistem yang lebih berkeadilan dan perluasan basis data perpajakan yang lebih valid, komprehensif, dan terintegrasi, serta (3) meningkatkan penerimaan pajak.

\section{Pengetahuan Pajak}

Menurut (Carolina, 2009), pengetahuan pajak merupakan suatu informasi pajak yang dapat digunakan wajib pajak sebagai dasar untuk bertindak, mengambil keputusan, serta untuk menentukan strategi tertentu yang berhubungan dengan pelaksanaan hak dan kewajiban di bidang perpajakan. Menurut Nugraheni (2015) dalam (Sari, 2017), jika wajib pajak memiliki pengetahuan dan pemahaman yang memadai mengenai peraturan perpajakan, maka dapat dipastikan wajib pajak secara sadar akan patu dalam melaksanakan kewajiban perpajakannya dengan baik da benar. Sehingga, wajib pajak akan terhindar dari pengenaan sanksi pajak yang berlaku.

\section{Sanksi Perpajakan}

Sanksi perpajakan adalah jaminan bahwa ketentuan peraturan perundangundangan perpajakan (norma perpajakan) akan dituruti/dipatuhi. Dengan kata lain, sanksi perpajakan merupakan alat pencegah agar wajib pajak tidak melanggar norma perpajakan (Mardiasmo, 2009).

Sanski pajak terdiri dari atas sanksi administrasi dan sanksi pidana. Sanksi administrasi adalah pembayaran kepada Negara, khususnya berupa bunga dan kenaikan. Sanksi administrasi dibedakan menjadi tiga yaitu sanksi berupa bunga, sanksi berupa denda administrasi, dan sanksi berupa kenaikan. Sedangkan sanksi pidana adalah siksaan atau penderitaan. Sanksi pidana merupakan suatu alat terakhir yang digunakan fiskus agar norma perpajakan dipatuhi (Mardiasmo, 2009); (Resmi, 2014).

\section{Kepatuhan Wajib Pajak}

Kepatuhan wajib pajak adalah kondisi dimana wajib pajak memenuhi semua kewajiban perpajakannya dan melaksanakan hak perpajakannya (Nurmantu, 2005). Lebih lanjut, (Nurmantu, 2005) menyatakan bahwa wajib pajak dikatakan patuh apabila wajib pajak memenuhi semua kewajiban perpajakannya dan melaksanakan hak perpajakannya.

\section{Pengembangan Hipotesis Pengaruh Pelayanan Fiskus Terhadap Kepatuhan Wajib Pajak}

Pelayanan fiskus atau pelayanan dalam bidang perpajakan didefinisikan sebagai pelayanan yang diberikan kepada wajib pajak oleh Direktorat Jenderal Pajak untuk membantu wajib pajak memenuhi kewajiban perpajakannya (Jotopurnomo \& Mangoting, 2013). Lebih lanjut, (Jotopurnomo \& Mangoting, 2013) menyatakan bahwa pelayanan pajak merupakan jenis pelayanan publik. Sehingga, pelayanan tersebut bertujuan untuk memenuhi kebutuhan masyarakat 
ataupun untuk menjalankan undangundang, serta pelayanan tersebut tidak ditunjukan untuk mencari laba.

Pemberian pelayanan yang baik diharapkan dapat meningkatkan tingkat pengharapan wajib pajak pada pemenuhan kepentingan yang wajib pajak inginkan. Sehingga, pemberian pelayanan yang baik oleh fiskus diharapkan dapat meningkatkan kepatuhan wajib pajak. Pernyataan ini didukung oleh hasil penelitian (Astuti \& Achadiyah, 2016); (Jotopurnomo \& Mangoting, 2013); (Rohmawati \& Rasmini, 2012); (Hardiningsih \& Yulianwati, 2011) yang menyatakan bahwa pelayanan fiskus memengaruhi kepatuhan wajib pajak. Oleh karena itu, hipotesis pertama penelitian ini adalah sebagai berikut:

\section{$\mathrm{H} 1$ : pelayanan fiskus berpengaruh terhadap kepatuhan wajib pajak}

\section{Pengaruh Tax Amnesty Terhadap Kepatuhan Wajib Pajak}

Menurut (Undang-Undang Republik Indonesia Nomor 11, 2016), tax amnesty (pengampunan pajak) sebagai penghapusan pajak yang seharusnya terutang, tidak dikenai sanksi administrasi dan sanksi pidana di bidang perpajakan dengan cara mengungkap harta serta membayar uang tebusan sebagaimana yang telah diatur dalam undang-undang tax amnesty. Lebih lanjut, (UndangUndang Republik Indonesia Nomor 11, 2016) menyatakan tujuan tax amnesty adalah (1) mempercepat pertumbuhan ekonomi dan restrukturisasi ekonomi, (2) mendorong reformasi perpajakan menuju sistem yang lebih berkeadilan serta peluasan basis data yang lebih valid, komprehensif, dan terintegrasi, serta (3) meningkatkan penerimaan pajak yang digunakan untuk membiayai pembangunan.

Menurut Pramushinta dan Siregar (2011) dalam (Sari, 2017), tax amnesty diharapkan menghasilkan penerimaan pajak yang selama ini belum dibayar. Selain, itu program tax amnesty diharapkan dapat meningkatkan kepatuhan serta efektivitas pembayaran pajak. Hal ini karena daftar kekayaan wajib pajak semakin akurat. Wajib pajak yang sebelumnya tidak patuh dengan mengikuti program tax amnesty diharapkan dapat menjadi wajib pajak yang patuh.

Menurut (Ngadiman \& Huslin, 2015), cara membangun kepatuhan wajib pajak sukarela setelah program tax amnesty yaitu dengan dilakukan transparansi atas penggunaan uang pajak serta alokasi dari penerimaan tersebut harus tepat sasaran dan berkeadilan. Pernyataan ini didukung oleh hasil penelitian (Sari, 2017), yang menyatakan bahwa program tax amnesty berpengaruh terhadap kepatuhan wajib pajak. Oleh karena itu, hipotesis kedua penelitian ini adalah sebagai berikut:

H2: tax amnesty berpengaruh terhadap kepatuhan wajib pajak

\section{Pengaruh Pengetahuan Pajak Terhadap Kepatuhan Wajib pajak}

Menurut (Mardiasmo, 2009) pengetahuan pajak adalah kemampuan wajib pajak dalam mengetahui peraturan perpajakan, baik mengenai tarif pajak dan manfaat dari membayar pajak. Pengetahuan pajak berperan penting dalam menumbuhkan kepatuhan wajib pajak. Oleh karena itu, ketika wajib pajak memiliki pengetahuan yang memadai maka wajib pajak tersebut akan mudah dalam melaksanakan kewajiban perpajakannya (Ghoni, 2014). Sehingga seiring dengan peningkatan pengetahuan pajak yang dimiliki oleh wajib pajak dapat memengaruhi patuh atau tidaknya wajib pajak. Hal ini karena wajib pajak sudah mengetahui atas konsekuensi maupun sanksi yang akan diterima ketika wajib pajak tidak melakukan kewajibannya dengan benar (Zuhdi, Topowijoyo, \& Azizah, 2015). Pernyataan ini sesuai dengan hasil penelitian (Ghoni, 2014); (Susilawati \& Budiartha, 2013); (Adiasa, 2013); (Rohmawati \& Rasmini, 2012); (Witono, 2008) yang menyatakan bahwa pengetahuan perpajakan berpengaruh terhadap kepatuhan wajib pajak. Oleh karena itu, hipotesis ketiga penelitian ini adalah sebagai berikut:

H3: pengetahuan perpajakan berpengaruh terhadap kepatuhan wajib pajak 


\section{Pengaruh Sanksi Pajak Terhadap Kepatuhan Wajib Pajak}

Menurut (Resmi, 2014), sanksi pajak terjadi karena adanya pelanggaran terhadap peraturan perundang-undangan perpajakan. Sanksi pajak merupakan jaminan bahwa ketentuan peraturan perundang-undangan perpajakan (norma perpajakan) akan dituruti atau dipatuhi. Dengan kata lain, sanksi perpajakan merupakan alat pencegah agar wajib pajak tidak melanggar norma perpajakan (Mardiasmo, 2009). Faktor terbesar yang memengaruhi kepatuhan wajib pajak adalah sanksi pajak. Hal ini berhubungan dengan sanksi yang tidak ringan yang diterima oleh wajib pajak ketika melakukan suatu keterlambatan atau bahkan melakukan pelanggaran administratif maupun pidana terhadap penetapan pajak. Pernyataan ini didukung oleh hasil penelitian (Irmawati \& Hidayatulloh, 2019); (Siregar, 2017); (Rahayu, 2017); (Susilawati \& Budiartha, 2013); (Rohmawati \& Rasmini, 2012) yang menyatakan bahwa sanksi pajak berpengaruh terhadap kepatuhan wajib pajak. Oleh karena itu, hipotesis keempat penelitian ini adalah sebagai berikut:

$\mathrm{H} 4$ : sanksi pajak berpengaruh terhadap kepatuhan wajib pajak

Dari uraian pengembangan hipotesis sebelumnya, maka rerangka penelitian ini dapat digambarkan sebagai berikut:

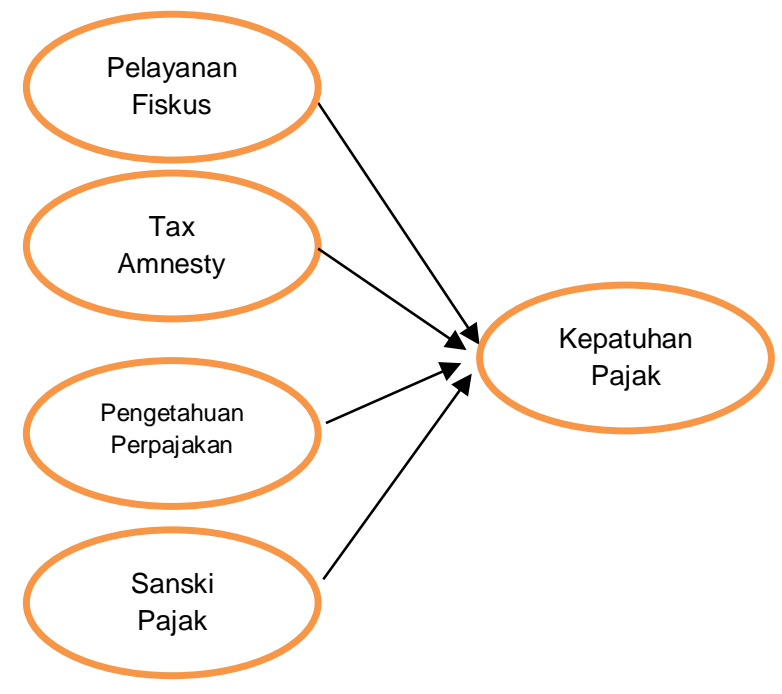

\section{Gambar 1. Rerangka Penelitian}

\section{METODOLOGI PENELITIAN}

Populasi dalam penelitian ini adalah wajib pajak orang pribadi yang berada di kota Yogyakarta. Sampel dalam penelitian ini adalah wajib pajak orang pribadi yang berada di kota Yogyakarta dan wajib pajak tersebut mengikuti program tax amnesty. Teknik pengambilan yang digunakan dalam penelitian ini adalah convenience sampling, yaitu memilih sampel dari elemen populasi (orang atau kejadian) yang peneliti mudah mendapatkan datanya (Sugiyono, 2015).

Penelitian ini terdiri dari satu variabel dependen, dan empat variabel independen. Variabel dependen dalam penelitian ini adalah kepatuhan wajib pajak. Sedangkan, variabel independen dalam penelitian ini adalah pelayanan fiskus, tax amnesty, pengetahuan perpajakan, dan sanksi pajak.

Kepatuhan wajib pajak didefinisikan sebagai kondisi wajib pajak untuk memenuhi semua kewajiban perpajakannya dan melaksanakan hak perpajakannya (Nurmantu, 2005). Variabel kepatuhan wajib pajak diukur dengan menggunakan skala likert lima poin (sangat setuju (5), setuju (4), raguragu (3), tidak setuju (2), dan sangat tidak setuju (1)). Indikator variabel kepatuhan wajib pajak terdiri dari lima item pertanyaan yang diadopsi dari (Rohmawati \& Rasmini, 2012).

Menurut (Jotopurnomo \& Mangoting, 2013), pelayanan fiskus didefinisikan sebagai pelayanan yang diberikan kepada wajib pajak oleh Direktorat Jenderal pajak untuk membantu wajib pajak dalam memenuhi kewajiban perpajakannya. Variabel pelayanan fiskus diukur dengan menggunakan skala likert lima point (sangat setuju (5), setuju (4), ragu-ragu (3), tidak setuju (2), dan sangat tidak setuju (1)). Indikator variabel pelayanan fiskus terdiri dari lima item pertanyaan yang diadopsi dari (Rohmawati \& Rasmini, 2012).

Menurut (Undang-Undang Republik Indonesia Nomor 11, 2016), tax amnesty didefinisikan sebagai penghapusan pajak yang seharusnya terutang, tidak dikenai 
sanksi administrasi perpajakan dan sanksi pidana dibidang perpajakan dengan cara mengungkap harta serta membayar uang tebusan. Variabel tax amnesty diukur dengan menggunakan skala likert lima point (sangat setuju (5), setuju (4), raguragu (3), tidak setuju (2), dan sangat tidak setuju (1)). Indikator variabel tax amnesty terdiri dari lima item pertanyaan yang diadopsi dari (Sari, 2017).

Pengetahuan pajak adalah kemampuan wajib pajak dalam mengetahui peraturan perpajakan, baik mengenai tarif pajak dan manfaat dari membayar pajak (Mardiasmo, 2009). Variabel pengetahuan pajak diukur dengan menggunakan skala likert lima point (sangat setuju (5), setuju (4), raguragu (3), tidak setuju (2), dan sangat tidak setuju (1)). Indikator variabel pengetahuan pajak terdiri dari lima item pertanyaan yang diadopsi dari (Witono, 2008).

Menurut (Mardiasmo, 2009), sanksi pajak didefinisikan sebagai jaminan bahwa ketentuan peraturan perundangundangaan (norma perpajakan) akan dituruti atau dipatuhi. Variabel pengetahuan pajak diukur dengan menggunakan skala likert lima point (sangat setuju (5), setuju (4), ragu-ragu (3), tidak setuju (2), dan sangat tidak setuju (1)). Indikator variabel pelayanan fiskus terdiri dari lima item pertanyaan yang diadopsi dari (Rohmawati \& Rasmini, 2012).

Analisis data dalam penelitian meliputi uji kualitas data, uji asumsi klasik, dan uji hipotesis. Uji kualitas data terdiri dari uji validitas dan uji reliabilitas. Uji asumsi klasik terdiri dari uji normalitas, uji multikolinieritas, dan uji heteroskesdasitas. Sedangkan uji hipotesis terdiri dari adjusted $R$-Square, uji $F$, dan uji t. Analisis dalam penelitian ini menggunakan alat SPSS.

\section{HASIL DAN PEMBAHASAN}

Responden dalam penelitian berjumlah 60 orang yang didominasi oleh responden berjenis kelamin perempuan (55\%), dan $45 \%$ responden berjenis kelamin laki-laki. Usia responden didominasi oleh usia 36-40 tahun (28,3\%), dan tingkat pendidikan responden didominasi oleh strata-1 (S-1) sebesar $48,3 \%$. Deskripsi usia dan tingkat pendidikan lebih detail disajikan pada tabel 1.

Tabel 1. Deskriptif Responden

\begin{tabular}{|c|c|c|c|}
\hline $\begin{array}{c}\text { Data } \\
\text { Deskriptif }\end{array}$ & Keterangan & Jumlah & $\begin{array}{c}\text { Persentas } \\
\text { e }\end{array}$ \\
\hline \multirow[t]{6}{*}{ Usia } & 20-25 tahun & 4 & $6,7 \%$ \\
\hline & 26-30 tahun & 11 & $18,3 \%$ \\
\hline & 31-35 tahun & 15 & $25 \%$ \\
\hline & 36-40 tahun & 17 & $28,3 \%$ \\
\hline & 41-45 tahun & 10 & $16,7 \%$ \\
\hline & $>45$ tahun & 3 & $5 \%$ \\
\hline \multirow{3}{*}{$\begin{array}{l}\text { Tingkat } \\
\text { Pendidikan }\end{array}$} & SMA & 27 & $45 \%$ \\
\hline & S1 & 29 & $48,3 \%$ \\
\hline & S2 & 4 & $6,7 \%$ \\
\hline
\end{tabular}

Sumber: data diolah (2018)

Teknik analisis data dalam penelitian ini menggunakan analisis regresi linear berganda. Hasil analisis data penelitian ini disajikan pada tabel 2 .

Tabel 2. Hasil Analisis Data

\begin{tabular}{|l|c|c|c|}
\hline \multicolumn{1}{|c|}{ Variabel } & Koefisiensi & $\begin{array}{c}\text { Signifikan } \\
\text { si }\end{array}$ & Alpha \\
\hline $\begin{array}{l}\text { Pelayanan } \\
\text { Fiskus }\end{array}$ & 4.592 & 0,000 & 0,05 \\
\hline Tax Amnesty & 2.583 & 0,012 & 0,05 \\
\hline $\begin{array}{l}\text { Pengetahuan } \\
\text { Pajak }\end{array}$ & -493 & 0,624 & 0,05 \\
\hline Sanksi Pajak & 1.464 & 0,149 & 0,05 \\
\hline Konstanta & 1.779 \\
\hline Adjusted R Square & 0,704 \\
\hline F Statistik & 36.157 \\
\hline Signifikansi & 0,000 \\
\hline \multicolumn{2}{|l}{ Sumber: da diah (2018). }
\end{tabular}

Sumber: data diolah (2018).

Tabel 2 menunjukan bahwa nilai adjusted $R$-Square sebesar 0,704 . Hal ini berarti bahwa variabel kepatuhan pajak dapat dijelaskan oleh variabel pelayanan fiskus, tax amnesty, pengetahuan pajak, dan sanksi pajak sebesar $70,4 \%$, dan $29,6 \%$ persen dijelaskan oleh variabel lain di luar model penelitian ini.

Tabel 2 juga menunjukan bahwa hasil uji $F$ memiliki nilai signifikasi $(0,000)$ yang lebih kecil dibandingkan dengan 
0,05 . Sehingga, dari hasil tersebut dapat diambil simpulan bahwa salah satu variabel independen (pelayanan fiskus, tax amnesty, pengetahuan pajak, dan sanksi pajak) ada yang berpengaruh terhadap variabel dependen (kepatuhan wajib pajak).

Lebih lanjut, tabel 2 juga menunjukan hasil uji t, yang memperoleh hasil bahwa pelayanan fiskus dan tax amnesty berpengaruh terhadap kepatuhan wajib pajak. Hal ini dapat dilihat dari masing-masing nilai signifikasi $(0,000)$ dan 0,012 ) yang lebih kecil dibandingkan dengan 0,05 . Oleh karena itu, hipotesis pertama $\left(\mathrm{H}_{1}\right)$ dan hipotesis kedua $\left(\mathrm{H}_{2}\right)$ penelitian ini terdukung. Akan tetapi, hipotesis ketiga $\left(\mathrm{H}_{3}\right)$ dan hipotesis keempat $\left(\mathrm{H}_{4}\right)$ penelitian ini tidak terdukung. Hal ini dapat dilihat dari masing-masing signifikasi $(0,624)$ dan $(0,149)$ yang lebih besar dibandingkan 0,05 . Sehingga dapat disimpulkan, bahwa pengetahuan pajak dan sanksi pajak tidak berpengaruh terhadap kepatuhan wajib pajak.

Kepatuhan wajib pajak dipengaruhi oleh pelayanan fiskus. Hal ini berarti bahwa beberapa indikator pelayanan fiskus yang sepenuhnya sudah dilaksanakan dengan baik, maka wajib pajak akan lebih termotivasi untuk membayarkan pajaknya. Pernyataan ini didukung oleh hasil penelitian (Astuti \& Achadiyah, 2016); (Jotopurnomo \& Mangoting, 2013); (Rohmawati \& Rasmini, 2012); (Hardiningsih \& Yulianwati, 2011) yang menyatakan bahwa pelayanan fiskus memengaruhi kepatuhan wajib pajak.

Program tax amnesty juga memengaruhi kepatuhan wajib pajak. Hal ini berarti bahwa pelayanan tax amnesty, khususnya di kota Yogyakarta mampu memberikan stimulasi kepada wajib pajak untuk meningkatkan kepatuhan wajib pajak. Oleh karena itu, dengan adanya program tax amnesty maka dapat menambah jumlah wajib pajak yang terdaftar. Sehingga, wajib pajak tersebut dapat memulai memenuhi kewajibannya dalam bidang pajak. Pernyataan ini didukung oleh hasil penelitian (Sari, 2017) yang memperoleh hasil bahwa program tax amnesty berpengaruh terhadap kepatuhan pajak.

Kepatuhan wajib pajak tidak dipengaruhi oleh pengetahuan pajak. Hal ini berarti bahwa tingkat pemahaman mengenai tata cara pembayaran dan pelaporan yang dimiliki wajib pajak masih kurang. Hal ini mungkin karena kurangnya sosialisasi dari pihak fiskus. Pernyaataan ini didukung oleh hasil penelitian (Hardiningsih \& Yulianwati, 2011), yang menyatakan bahwa pengetahuan perpajakan tidak berpengaruh terhadap niat wajib pajak untuk membayar pajak.

Sanksi pajak tidak berpengaruh terhadap kepatuhan wajib pajak. Hal ini berarti bahwa persepsi wajib pajak mengenai sanksi administrasi dan pidana yang masih ringan. Oleh karena itu, diperlukan tindak lanjut oleh pemerintah. Pernyataan ini didukung oleh hasil penelitian (Ermawati \& Afifi, 2018) yang menyatakan bahwa sanksi pajak tidak berpengaruh terhadap kepatuhan wajib pajak.

\section{KESIMPULAN}

Kepatuhan wajib pajak dipengaruhi oleh pelayanan fiskus dan program tax amnesty. Pelayanan fiskus yang sepenuhnya sudah dilaksanakan dengan baik akan meningkatkan kepatuhan wajib pajak. Begitu juga dengan program tax amnesty, yang dapat memberikan stimulasi kepada wajib pajak untuk bersikap patuh. Namun, pengetahuan perpajakan dan sanksi pajak tidak berpengaruh terhadap kepatuhan wajib pajak. Hal ini karena pemahaman mengenai tata cara pembayaran dan pelaporan pajak yang dimiliki oleh wajib pajak masih kurang. Sehingga, pemerintah perlu meningkatkan aktivitas sosialisasi kepada wajib pajak. Wajib pajak juga masih menganggap bahwa sanksi administrasi maupun sanksi pidana yang dikenakan apabila melanggar undang-undang perpajakan masih ringan. Oleh karena itu, pemerintah harus mengkaji ulang mengenai sanksi pajak yang sudah ditetapkan. 


\section{IMPLIKASI DAN \\ KETERBATASAN}

Penelitian ini memiliki implikasi teori dan praktis. Implikasi teori penelitian ini adalah penelitian ini memperluas penelitian pada bidang perpajakan, khusunya mengenai kepatuhan pajak. selain itu, penelitian ini memberikan bukti bahwa pelayanan fiskus dan program tax amnesty merupakan faktor yang memengaruhi kepatuhan wajib pajak. Penelitian ini juga memberikan bukti bahwa kepatuhan wajib pajak tidak dipengaruhi oleh pengetahuan dan sanksi pajak.

Implikasi praktis penelitian ini adalah penelitian ini dapat digunakan oleh pemerintah, khususnya direktorat jenderal pajak mengenai faktor yang memengaruhi kepatuhan wajib pajak. Faktor tersebut antara lain pelayanan fiskus dan program tax amnesty. Sehingga, dari hasil ini penelitian ini diharapkan pemerintah atau direktorat jenderal pajak dapat memberikan pelayanan yang baik kepada wajib pajak, serta mengeluarkan program yang terkait bidang perpajakan yang dapat meningkatkan kepatuhan wajib pajak.

Peneliti menyadari tidak ada penelitian yang terlepas dari keterbatasan. Keterbatasan penelitian ini adalah penelitian ini memiliki vadilitas internal yang rendah. Hal tersebut disebabkan karena penelitian ini menggunakan metoda survey. Oleh karena itu, penelitian selanjutanya dapat menggunakan metoda kualitatif maupun eksperimen agar menghasilan validitas internal yang tinggi.

\section{REFERENCES}

Adiasa, N. (2013). Pengaruh Pemahaman Peraturan Pajak Terhadap Kepatuhan Wajib Pajak Dengan Moderating Preferensi Risiko. Accounting Analysis Journal, 2(3).

Arum, H. P. (2012). Pengaruh Kesadaran Wajib Pajak, Pelayanan Fiskus, dan Sanksi Pajak Terhadap Kepatuhan Wajib Pajak Orang Pribadi Yang Melakukan Kegiatan Usaha dan Pekerjaan Bebas (Studi di Wilayah KPP Pratama Cilacap) (Universitas Diponegoro Semarang). Retrieved from

http://eprint.undip.ac.id/35890/1/SKR IPSI_ARUM.pdf

Astuti, D., \& Achadiyah, B. N. (2016). Pengaruh Sosialisasi Perpajakan, Pelayanan Fiskus, dan Pelaksanaan Self Assessment System Terhadap Tingkat Kepatuhan Wajib Pajak Rumah Kos. Jurnal Nominal, 5(1).

Carolina, V. (2009). Pengetahuan Pajak. Jakarta: Salemba Empat.

Ermawati, N., \& Afifi, Z. (2018). Pengaruh Pengetahuan Perpajakan dan Sanksi Perpajakan Terhadap Kepatuhan Wajib Pajak Dengan Religiusitas Sebagai Variabel Pemoderasi. Prosiding SENDI_U.

Finansial.bisnis.com. (2018). Pengampunan Pajak 38 Negara Sudah Terapkan Tax Amnesty. Http://Finansial.Bisnis.Com.

Retrieved from http://finansial.bisnis.com/read/2016 0901/10/580310/pengampunanpajak-38-negara-sudah-terapkantax-amnesty

Ghoni, A. (2014). Pengaruh Motivasi dan Pengetahuan Wajib Pajak Terhadap Kepatuhan Wajib Pajak Daerah. Jurnal Akuntansi UNESS, 1(1).

Hardiningsih, P., \& Yulianwati, N. (2011). Faktor-Faktor Yang Mempengaruhi Kemauan Membayar Pajak. Dinamika Keuangan Dan Perbankan, 3(1).

Irmawati, J., \& Hidayatulloh, A. (2019). Determinan Kepatuhan Wajib Pajak UMKM di Kota Yogyakarta. Jurnal Sistem Informasi, Keuangan, Auditing Dan Perpajakan, 3(2), 112121.

Jatmiko, A. N. (2006). Pengaruh Sikap Wajib Pajak Pada Pelaksanaan Sanksi Denda, Pelayanan Fiskus, dan Kesadaran Perpajakan Terhadap Kepatuhan Wajib Pajak (Universitas Diponogoro). Retrieved from http://eprints.undip.ac.id/15261/1/Ag us Nugroho Jatmiko.pdf. 02November 2017

Jotopurnomo, C., \& Mangoting, Y. (2013). Pengaruh Kesadaran Wajib Pajak, Kualitas Pelayanan Fiskus, Sanksi Perpajakan, Lingkungan Wajib Pajak 
Berada Terhadap Kepatuhan Wajib pajak Orang Pribadi di Surabaya. Tax and Accounting Review, 1(1).

Mardiasmo. (2009). Perpajakan, Edisi Revisi 2009. Yogyakarta: Andi Offset.

Muliasari, N. K., \& Setiawan, P. E. (2011). Pengaruh Persepsi Tentang Sanksi Perpajakan dan Kesadaran Wajib Pajak Pada Kepatuhan Pelaporan Wajib Pajak Orang Pribadi di Kantor Pelayanan Pajak Pratama Denpasar Timur. Jurnal Ilmiah Akuntansi Dan Bisnis, 6(1).

Mulyani, S. (2018). Penerimaan pajak Januari 2018 Pecahkan Rekor Tembus Rp7.894 Triliun. Http://Jogja.Tribunnews.Com.

Retrieved from http://jogja.tribunnews.com

Ngadiman, \& Huslin. (2015). Pengaruh Sunset Policy, Tax Amnesty, dan Sanksi Pajak Terhadap Kepatuhan Wajib Pajak (Studi Empiris di Kantor Pelayanan Pajak Pratama Jakarta Kembangan). Jurnal Akuntansi, 19(2).

Nurmantu, S. (2005). Pengantar Perpajakan Ed.3. Jakarta: Granit.

Ragimun. (2015). Analisis Implementasi Amnesti pajak di Indonesia. Www.Kemenkeu.Go.ld. Retrieved from www.kemenkeu.go.id

Rahayu, N. (2017). Pengaruh Pengetahuan Perpajakan, Ketegasan Sanksi Pajak, dan tax amnesty Terhadap Kepatuhan Wajib Pajak. Akuntansi Dewantara, 1(1).

Resmi, S. (2014). Perpajakan: Teori dan kasus. Jakarta: Salemba Empat.

Rezy, F. (2016). Tax Amnesty Perkuat Tujuan Pembangunan Nasional. Http://Economy.Okezone.Com.

Retrieved from http://economy.okezone.com

Rohmawati, A. N., \& Rasmini, N. K. (2012). Pengaruh Kesadaran, Penyuluhan, Pelayanan, dan Sanksi Perpajakan Pada Kepatuhan Wajib Pajak Orang Pribadi. E-Jurnal Akuntansi Universitas Udayana, 1(1).

Sari, V. A. P. (2017). Pengaruh tax amnesty, pengetahuan perpajakan, dan pelayanan fiskus terhadap kepatuhan wajib pajak. Jurnal IImu Dan Riset Akuntansi, 6(2).

Siamena, E., \& Sabijono, Hariyanto Warongan, J. D. (2017). Pengaruh Sanksi Perpajakan dan Kesadaran Wajib Pajak Terhadap Kepatuhan Wajib Pajak Orang Pribadi di Manado. Jurnal Riset Akuntansi Going Concern, 1(2).

Siregar, D. L. (2017). Pengaruh Kesadaran Wajib Pajak dan Sanksi Pajak Terhadap Kepatuhan Wajib Pajak Orang Pribadi Pada Kantor Pelayanan Pajak Pratama Batam. Journal of Accounting and Management Innovation, 1(2).

Sugiyono. (2015). Metodologi Penelitian Bisnis. Bandung: Alfabeta.

Susilawati, K. E., \& Budiartha, K. (2013). Pengaruh Kesadaran Wajib pajak, Pengetahuan Pajak, Sanksi Perpajakan, dan Akuntabilitas Pelayanan Publik Pada Kepatuhan Wajib Pajak Kendaraan Bermotor. EJurnal Akuntansi Universitas Udayana, 4(2).

Tiraada, T. A. (2013). Kesadaran Perpajakan, Sanksi Pajak, Sikap Fiskus Terhadap Kepatuhan WPOP di Kabupaten Minahasa Selatan. Jurnal EMBA, 1(3).

Undang-undang Nomor 28. (2007).Tentang Ketentuan Umum dan Tata Cara Perpajakan.

Undang-Undang Republik Indonesia Nomor 11 . (2016).Tentang Pengampunan Pajak.

Witono, B. (2008). Peranan pengetahuan pajak pada kepatuhan wajib pajak. Jurnal Perpajakan, 7(2), 196-208.

www.kemenkeu.go.id. (2018).

Zuhdi, F. A., Topowijoyo, \& Azizah, D. F. (2015). Pengaruh Penerapan E-SPT dan Pengetahuan Perpajakan Terhadap Kepatuhan Wajib pajak (Studi Kasus Pengusaha Kena Pajak Yang Terdaftar di KPP Pratama Singosari). Jurnal Perpajakan (JEJAK), 7(1), 193-206. https://doi.org/10.1007/978-3-531 92674-2 11 